\title{
18
}

\section{What is the Mainstream? The Laws of First Nations Peoples}

\author{
Irene Watson ${ }^{1}$
}

\section{Introduction}

The business of colonialism is not yet finished; it rolls on relentlessly. This fact presents us with certain challenges. For Australia, the legal limit in dealing with the fact of First Nations Peoples' existence was reiterated by the High Court in Mabo (No 2). ${ }^{2}$ It determined that the extent of recognition of First Nations cannot move beyond the 'skeletal' principle which is the foundation of the colonial state. ${ }^{3}$

As a result of this position taken by the High Court, one that has been restricted even further by the Australian state, ${ }^{4}$ the genocide of First Nations is able to continue. ${ }^{5}$ As a parallel, but as part of the same project,

1 Research Professor of Law, University of South Australia. I acknowledge the support of an ARC Indigenous Discovery Award which enabled me to work on the project Indigenous Knowledges: Law, Society and the State. I also acknowledge the research assistance of Jo Bird and Emily Collins.

2 Mabov Queensland (No 2) (1992) 175 CLR 1.

3 Ibid. 30.

4 Native Title Act 1993 (Cth). For a discussion of the limitations of this Act, see Irene Watson, 'Sovereign Spaces, Caring for Country and the Homeless Position of Aboriginal Peoples' (2009) 108 South Atlantic Quarterly 27; Irene Watson, Aboriginal Peoples, Colonialism and International Law: Raw Law (Routledge, 2015).

5 On genocide, see Watson, Aboriginal Peoples, above n 4, 109-44. 
Australia still holds records for animal and plant extinctions and our territories are threatened with ecocide with each new and damaging development proposal. ${ }^{6}$

While this chapter sits within an environment stream, which includes resources, Indigenous relationships to the environment and property, my call for reform crosses all areas of the law, so the cast of the chapter is much broader. Western legal systems are segmented and categorised into property, contract, torts and so on; First Nations' legal systems are relational. This chapter will embrace the complexity of First Nations' legal systems and the problem of having to fit Aboriginal laws within colonial foundations. In the near future the challenges will be immense and those formulating the legal and policy responses should be aware of those complexities. So where to begin?

\section{Where to Begin}

We need to move beyond the politics of recognition: politics which are limited by the colonial foundations of the state. ${ }^{7}$ These foundations pass as law, but it is military power and colonial violence that are the foundations of the colonising project called Australia, a project which continues to this day. The urgency of our time calls for law, certainly, but my argument is not so much for the reform of Euro-centric law, because its colonial foundation is unlawful, but instead for the re-emergence of the ancient laws of this continent now called Australia. ${ }^{8}$

6 For example, Australia has the highest rate of mammal extinction in the world. Globally, over the past 400 years, one in three mammal extinctions have occurred in Australia. A 2015 review of the literature indicates that since 1788, 28 species of Australian land mammals have become extinct. Compare this with post-invasion North America, in which only one mammal species has become extinct over more than 400 years. See John Woinarski, Andrew Burbidge and Peter Harrison, 'Ongoing Unravelling of a Continental Fauna: Decline and Extinction of Australian Mammals since European Settlement' (2015) 112 Proceedings of the National Academy of Sciences 4531. For information on flora both extinct and threatened, see Department of the Environment and Energy, EPBC Act List of Threatened Flora, www.environment.gov.au/cgi-bin/sprat/public/publicthreatenedlist. pl?wanted=flora; and, for a comparison with international data, see 'Fact Check: Does Australia Have One of the "Highest Loss of Species Anywhere in the World"?', ABC News, 4 March 2016, www.abc. net.au/news/2015-08-19/fact-check-does-australia-have-one-of-the-highest-extinction/6691026.

7 I discuss the politics of recognition in Watson, Aboriginal Peoples, above n 4, 18.

8 For further discussion see ibid. 
The Australian state continues to run on an unlawful foundation; the opportunity to review this position was presented in Mabo (No 2), but the High Court decided there was no possibility other than to retain the skeleton principle of colonial Australia's foundation. So are we stuck with this, an unlawful foundation that, regardless of Mabo (No 2)'s rejection of terra nullius, also rejects the continuity of Aboriginal laws? We now have affirmed the unlawfulness of the terra nullius state, but with no alternative in its place.

I propose another truth, another way of knowing law, a way which was the 'mainstream law' for this continent for millennia, since the first sunrise, a way which still lives as the laws of the land to this day. The laws of the land are ancient and as old as the continent itself; they continue to exist. The laws of the land cannot be finished, other than perhaps in the minds of those humans who proclaim their ending. But law continues, just as the natural world continues, regardless of how it may be denied by humans. For that is the law.

The reform I advocate is that the colonial settler society should better see and know this law, so that it becomes visible to those who cannot see it beneath the continuing cover of terra nullius. It is a radical call, one which calls for us to begin again. It may be an impossible call, but not to respond to it and to do nothing presages an impossible future, not only for humans, but for all life on earth.

At this stage some readers may be thinking 'Can't we have our cake and eat it?', but we can't do that anymore. The dire consequences if we do have been pointed out many times.

\section{Beyond the Politics of Recognition}

Kombu-Merri and Waka Waka elder and philosopher Mary Graham has argued that First Nations have managed this country forever and that we still have the authority to do so today. ${ }^{9}$ Clearly we do not have the power beyond the 'recognition' politics of the colonial state but we do still hold the lawful authority to carry out ancient obligations to care for country.

9 Mary Graham, 'Some Thoughts about the Philosophical Underpinnings of Aboriginal Worldviews' (2008) 45 Australian Humanities Review 181, www.australianhumanitiesreview.org/ archive/Issue-November-2008/graham.html. 
Many First Nations share the obligation to care for country; it is in our laws to ensure that future generations - not only human but all species, including our ngaitji ${ }^{10}$ relations - have a sustainable future. Many First Nations understand that this is law which is core to our being and hold this core even in the face of the colonial assimilation policies that were intended to destroy our connections to law.

The challenge for non-Indigenous Australians is to see First Nations Peoples and the laws of the land from another horizon, one of law outside and beyond the continuing terra nullius cover of the colonial project. That is to see beyond the commodification of land and the constructions of Aboriginality as backward and savage.

The dialogue we need to have must move beyond the current trajectory emanating from a politics of recognition to become one which listens to the laws of the land and acts lawfully in response. We need to move beyond pragmatism, short-term solutions, and political and economic gains and embrace the truth of the natural world and its ancient laws.

\section{International Law}

International law concepts such as self-determination, territorial integrity, and free, prior and informed consent have all been considered possible tools to transform coloniality. From within a critical First Nations' lens, concepts of self-determination, territorial integrity, and free, prior and informed consent have been considered for the possibility of coexistence beyond the current assimilationist framework we are subjected to.

Across my work I have considered the limitations of Euro-centred international and domestic laws on 'Indigenous recognition'. I have considered the illusion of recognition and have advocated for the real possibility of an ongoing existence based on Aboriginal laws and their inherent philosophy of relationality.

To continue the current 'progress and development' agenda is to ensure the decline of life on earth, and the death of many species. The possibility of our survival is enmeshed in relationships with all life forms and requires respect for Aboriginal laws and their core philosophies of relationality.

10 Our ngaitji represents the relationship or kinship we share with our surrounding natural world. It is a relationship that teaches us about the unity we share with all natural things. 
As I oppose the fracking and other developments of ancestral lands which I am related to and obliged to care for, the greater part of humanity is also tied to the matrix of like connections. ${ }^{11}$ We are all dependent upon air and water, and our airs and waters flow together and are connected.

The maintenance and centring of First Nations epistemologies is essential to survival. Is it then possible to reconstruct international law so that it is liberated from its colonial origins, and is replaced with or at least inclusive of First Nations laws, philosophies and knowledges?

\section{First Nations Epistemologies}

If First Nations are not positioned to reframe the dialogue (as we are not currently), then coloniality will continue and with it the same old destructive development agenda. A horizontal dialogue between colonialist interests and First Nations-centred epistemologies is essential to human survival. We must put the discussion of Indigenous rights at the centre of the debate, moving beyond the literature on colonially constructed identities. Current human-rights frameworks ignore our core role as carers for the land for future generations; the fullness of Indigenous epistemologies is misunderstood and also ignored. Our inherent connectedness to the natural world is ignored and remains largely unfathomable to the nonIndigenous world. The critical need for another way of being law-full is not known or is currently incapable of being seen. Opening our eyes widely and seeing and knowing law is critical.

\section{Recognition: The Mainstream Context}

Aboriginal law has run and continues to run across Aboriginal lands; it remains the invisible mainstream law. But it continues to be rendered invisible by the colonial project, which continues today even though its existence is denied.

11 Irene Watson and Kungari Aboriginal Heritage Association, Submission No 103 to Parliament of South Australia Natural Resources Committee, Inquiry into Unconventional Gas (Fracking) in the South East of South Australia, 29 January 2015; Irene Watson and Kungari Aboriginal Heritage Association, submission in response to Nora Creina Golf Course and Tourism Resort: Major Project Public Environmental Report, January 2016. 
The law is the law is the law. It just is, and no amount of violence and no colonial system established by force and constructing itself as 'law' will override or extinguish it. While the colonial legal system has constructed myths which emanate from terra nullius, they are just that - myths of nonexistence constructed for the purpose of enabling an unlawful foundation. Aboriginal laws remain the mainstream and, while First Nations are deemed peoples without law and merely objects of the colonial law, this is not the truth.

The colonial project posits and constructs rules which overlay the law of the land, rules which reject First Nations' laws as Aboriginal oral stories, and represent their reliance upon the memory of elders as mere myth and fable. While science is only now catching up with many of our stories and songs (as noted in a recent example concerning the rising waters which resulted in the Great Barrier Reef ${ }^{12}$ ), they are too often fobbed off as childlike, and their ancient coded knowledge of the codependence between humans and their environments remains unexamined.

Eurocentric law postures as being secular, and holds that the central position of spirituality and relationality in First Nations' laws means that they are not real law. But this position denies that the origins of Western Eurocentric legal systems were and remain founded upon religious law. Christianity both annihilated and excluded the 'heathen' because they were not Christians.

\section{Possibilities for Common Ground: What will Happen if We do Nothing?}

Critical sociologist and legal theorist Boaventura de Sousa Santos reminds us of our obligations beyond critical discourse and of the need for talk about the unspeakable when he warns of the risk of an epistemicide, the murder of knowledge, if the exclusion of 'different' voices continues. ${ }^{13}$ Although as I have said above the law is the law - it just is and it cannot be extinguished - the potential for juricide also looms if Aboriginal

12 Nick Reid and Patrick Nunn, 'Aboriginal Memories of Inundation of the Australian Coast Dating from More than 7000 Years Ago' (2016) 47 Australian Geographer 11.

13 Boaventura de Sousa Santos, Epistemologies of the South: Justice against Epistemicide (Paradigm Publishers, 2014). 
legal systems continue to be ignored. Perhaps it is more accurate to say that there is the potential for a death of knowledge of the law and its connection to the First Nations carriers of law.

Is there a possibility for common ground, or even a dialogue on these concerns, beyond the dominance of a Western-centric universalism and incommensurability between cultures? ${ }^{14}$ An equality of power relations, that is, relations of shared authority which could fit the purposes of intercultural translations, is the necessary precursor, since only then can reciprocity among social groups or movements be obtained. ${ }^{15}$

In thinking through this terrain, First Nations' critical approaches to vague and loaded concepts such as 'equality' remain essential. They are essential to the possibility of First Nations' voices being heard and not suppressed so as not even to register. ${ }^{16}$

I consider that the following questions and comments raised by Santos contribute to the possibility of our voices being heard by dominant colonial states:

- How do the power relations between First Nations and states translate into Western law?

- What place or space is there to speak of coloniality, for where is the world free of colonialism?

- Opening up the space is more than an intellectual process.

- Inter-cultural translation is an instrument for mediation and negotiation and can only flourish where there is a commitment to decolonising power relations.

What are the possibilities for First Nations' laws? How can we re-centre them and the natural world? First Nations' perspectives on authority and power should be central to any intercultural dialogue.

In understanding that the natural world holds authority, it would follow then that all places and spaces are open to being contact zones. We need to listen about climate change. We need to listen about coal mining and fracking, and to all events which affect our natural ecosystems.

14 Ibid. 212.

15 Ibid. 214.

16 Miranda Fricker, Epistemic Injustice: Power and the Ethics of Knowing (Oxford University Press, 2007). 
Our natural world is in crisis which makes the need for translation ever more urgent. ${ }^{17}$ The West has reached the end point of project progress, and does not have the solutions to the crisis. It has no other lands to invade and colonise beyond leaving our mother Earth and searching for other planets. Current regimes of recognition and protection do not work. We are on the brink of sacrificing our waters, our oceans and our lands which provide for an overpopulated planet. Recognition laws in respect of First Nations come in the form of native title laws ${ }^{18}$ and Aboriginal heritage protection, ${ }^{19}$ and they are accompanied by named environmental laws, ${ }^{20}$ but none of them have the capacity to protect the environments which are vital to our survival. We are on a trajectory which it appears could sacrifice all life forms, but we still have the capacity for ongoing life. Cycles do return, to begin again. Aboriginal law is an ongoing cycle; it is the law.

17 Santos, above n 13, 233.

18 Native Title Act 1993 (Cth); Native Title Amendment Act 1998 (Cth).

19 Aboriginal and Torres Strait Islander Heritage Protection Act 1984 (Cth).

20 Environment Protection and Biodiversity Conservation Act 1999 (Cth), among other Australian state and Commonwealth laws. 
This text is taken from New Directions for Law in Australia: Essays in Contemporary Law Reform, edited by Ron Levy, Molly O’Brien, Simon Rice, Pauline Ridge and Margaret Thornton, published 2017 by ANU Press, The Australian National University, Canberra, Australia. 